\title{
Growth, Yield and Quality of Maize under Ozone and Carbon Dioxide Interaction in North West India
}

Aerosol and Air Quality Research

\section{OPEN ACCESS}

Received: May 23, 2020

Revised: August 23, 2020

Accepted: September 4, 2020

${ }^{*}$ Corresponding Author: artibhatia.iari@gmail.com

Publisher:

Taiwan Association for Aerosol Research

ISSN: $1680-8584$ print

ISSN: 2071-1409 online

Copyright: The Author(s). This is an open access article distributed under the terms of the Creative Commons Attribution License (CC BY 4.0), which permits unrestricted use, distribution, and reproduction in any medium, provided the original author and source are cited.

\author{
Achchhelal Yadav ${ }^{1}$, Arti Bhatia ${ }^{2}$, Sudesh Yadav ${ }^{1}$, Archana Singh ${ }^{2}$, \\ Ritu Tomer², Ramesh Harit², Vinod Kumar², Bhupinder Singh² \\ 1 Jawaharlal Nehru University, New Delhi-110067, India \\ ${ }^{2}$ ICAR- Indian Agricultural Research Institute, New Delhi-110012, India
}

\begin{abstract}
Maize is an important $\mathrm{C}_{4}$ crop and how it will respond to elevated atmospheric carbon dioxide and ozone levels is not well documented. To understand how the growth and nutritional quality of maize will be affected under elevated carbon dioxide $\left(\mathrm{CO}_{2}\right)$ and tropospheric ozone $\left(\mathrm{O}_{3}\right)$ interaction, a field experiment was conducted under free air $\mathrm{O}_{3}$ and $\mathrm{CO}_{2}$ enrichment rings (FAOCE) growing HQPM-1 and PMH-1 maize cultivars at New Delhi, India. Each cultivar was exposed to ambient and elevated $\mathrm{CO}_{2}(559 \mathrm{ppm})$ alone and along with ambient and elevated $\mathrm{O}_{3}(71.8 \mathrm{ppb})$ throughout the growing period. Elevated $\mathrm{CO}_{2}(\mathrm{EC})$ significantly increased the leaf area index (10.8-22.5\%), chlorophyll (11.2-17.3\%) and photosynthetic rate (12.1-16.5\%) in the two cultivars over the ambient. $\mathrm{O}_{3}$ exposure of $27 \mathrm{ppm} \mathrm{hr}$ (AOT4O) under elevated $\mathrm{O}_{3}$ (EO) treatment led to a significant decline in yield $(p<0.01)$ by $9.2 \%$ in HQPM- 1 and $9.8 \%$ in PMH-1. Under elevated $\mathrm{CO}_{2}$ the increase in grain yield was higher under HQPM-1 $(25.4 \%)$ as compared to PMH-1 $(9.04 \%)$. The protein content increased under EO (8.1-12.5\%) and decreased under EC (13.4-13.6\%) in the two maize cultivars due to yield dilution effect. Lysine, phosphorus and potassium content of the grain significantly decreased in both the cultivars under elevated $\mathrm{CO}_{2}$. Carbohydrate and amylose concentrations in grains increased (9.9-15.5\%) under EC and decreased (10.8-16.7\%) under EO, however, no significant change in yield, protein, amylase, carbohydrate, lysine, potassium and phosphorus was observed under the interaction treatment ECO as compared to the ambient. After two years of study we could conclude that elevated $\mathrm{CO}_{2}(559 \mathrm{ppm})$ was able to offset the negative effect of elevated $\mathrm{O}_{3}(71 \mathrm{ppb})$ on grain yield by $11.2 \%$ in PMH-1 and by $18.8 \%$ in HQPM-1 without significantly affecting the grain quality in both the maize cultivars.
\end{abstract}

Keywords: Elevated carbon dioxide $\left(\mathrm{CO}_{2}\right)$, Tropospheric ozone $\left(\mathrm{O}_{3}\right)$, Crop growth, Yield, Nutritional quality

\section{INTRODUCTION}

Climate change and air pollution are increasing threats to agriculture production and food security (Porter et al., 2014; Tai et al., 2014). Due to the incessant burning of fossil fuels and anthropogenic activities, the concentration of $\mathrm{CO}_{2}$ has increased by $40 \%(400 \mathrm{ppm})$ since preindustrial era (1750 AD) and may increase to $550 \mathrm{ppm}$ by 2050 (IPCC, 2014). The greenhouse gases such as carbon dioxide $\left(\mathrm{CO}_{2}\right)$ and tropospheric ozone $\left(\mathrm{O}_{3}\right)$, also a phytotoxic air pollutant have bearings on plant growth and productivity. Atmospheric $\mathrm{CO}_{2}$ is a source of carbon assimilation in plants and works as a carbon fertilizer, resulting in improved plant growth and production (van der Kooi et al., 2016; Lopes et al., 2018). However, according to literature plants that use the $C_{4}$ photosynthetic pathway are less responsive to elevated $\mathrm{CO}_{2}$ as compared to plants that use the $\mathrm{C}_{3}$ pathway. Maize being a $\mathrm{C}_{4}$ plant, may thus behave differently under elevated $\mathrm{CO}_{2}$ as compared to $\mathrm{C}_{3}$ crops and there have been contrasting reports about the impact of elevated $\mathrm{CO}_{2}$ in maize. Abebe et al. (2016) observed an increase of $53.7 \%$ in the grain yield of maize whereas, Leakey et al. (2006) observed reductions in photosynthesis, biomass and yield under elevated $\mathrm{CO}_{2}$ condition. Furthermore, $\mathrm{CO}_{2}$ enrichment leads to a decline in nutrients present in the grains such as zinc, 
iron and protein content (Myers et al., 2014; Broberg et al., 2017). Previously it has been reported that elevated $\mathrm{CO}_{2}$ reduced $\mathrm{N}$, crude protein, $\mathrm{P}$ and $\mathrm{K}$ contents of grains (Abebe et al., 2016). Recently, Reich et al. (2018) observed a role reversal of the $C_{3}-C_{4}$ concept wherein they observed that after 12 year of experimentation, the biomass increased under elevated $\mathrm{CO}_{2}$ in $\mathrm{C}_{4}$ plants and decreased under $\mathrm{C}_{3}$ crops.

The concentration of ground level $\mathrm{O}_{3}$ is increasing continuously since industrial revolution and has reached $35-40 \mathrm{ppb}$ globally and it may continue to increase rapidly in the developing countries in the 21st century (Frei, 2015; Proietti et al., 2016; Sicard et al., 2017) According to Environmental Protection Agency if global emissions of $\mathrm{O}_{3}$ precursors continue at present day rate then the tropospheric $\mathrm{O}_{3}$ may reach more than $70 \mathrm{ppb}$ level by 2050 (Pfister et al., 2014). $\mathrm{O}_{3}$ is produced in the troposphere due to photochemical reactions of the oxides of nitrogen $\left(\mathrm{NO}_{\mathrm{x}}\right)$ and the volatile organic compounds (VOCs) including methane and $\mathrm{CO}_{2}$ (Bhatia et al., 2012). Several researchers reported that higher concentration of tropospheric $\mathrm{O}_{3}$ reduced carbon storage of crops, thereby reducing plant growth and yield (Bhatia et al., 2011; Zhu et al., 2011; Tai et al., 2014; Broberg et al., 2015; Tomer et al., 2015). The elevation of tropospheric $\mathrm{O}_{3}$ in the free air significantly increases $\mathrm{P}, \mathrm{K}$ and protein concentrations in the cereals (Pleijel et al., 2018). However, most of the research on the effect of elevated tropospheric $\mathrm{O}_{3}$ on photosynthesis and stomatal function has been carried out in $C_{3}$ species only (Ainsworth, 2017).

Besides the individual impacts of elevated $\mathrm{CO}_{2}$ and $\mathrm{O}_{3}$, the combined interaction of the elevated $\mathrm{CO}_{2}$ and $\mathrm{O}_{3}$ influence the crop growth and development. The enrichment of $\mathrm{CO}_{2}$ mitigated the adverse impacts of elevated $\mathrm{O}_{3}$ in many studies (Kumari et al., 2015; Phothi et al., 2016; Singh et al., 2018). Torbert et al. (2004) in a study in grain sorghum reported that elevated $\mathrm{CO}_{2}$ increased the total biomass production, however, the interactive influences of elevated $\mathrm{CO}_{2}$ and $\mathrm{O}_{3}$ have very rarely been studied in $\mathrm{C}_{4}$ crops. Bhatia et al. (2014) observed a significant reduction in the growth and yield of maize under elevated $\mathrm{O}_{3}$ in a study conducted in open top chambers. They reported that exposure of elevated (ambient $+40-45 \mathrm{ppb}$ ) $\mathrm{O}_{3}$ resulted in greater susceptibility of the maize plant to pest attack. Very few studies have been carried out in $C_{4}$ crops relative to $C_{3}$ crops and thus there is a generally a poorer understanding of $C_{4}$ responses to climate change (Leakey, 2009).

Maize a $\mathrm{C}_{4}$ cereal crop is the third most important crop after rice and wheat across the world. It is being produced in 189.3 million hectares and contributes $36 \%$ (1078 Mt) to the world food production (FAO, 2016) and about $70 \%$ of it is grown in the developing nations. In India, maize is mainly grown in Kharif season (June-October) with a total production of 24.4 million tons and 2.5 ton ha $^{-1}$ productivity, accounting for $9 \%$ of the total food grain production (Government of India, 2017). Due to the declining ground water tables and poor soil fertility in the rice growing areas of Indo-Gangetic Plains, maize has been suggested as an alternate crop to diversify from rice for improving soil quality and reducing the global warming potential of soils in this region. However, increasing concentration of tropospheric $\mathrm{O}_{3}$ in India, especially in the Indo-Gangetic Plains (IGP) is of major concern as it poses a threat to the quality and productivity of crops (Singh and Agrawal, 2017) and may reach 70 ppb by 2050 in South Asia (IPCC, 2014). Apart from this most of the studies on the impact of tropospheric $\mathrm{O}_{3}$ on crops have been conducted in Europe and America (temperate regions). Very few studies have been carried out in the tropical and semi-arid regions. Keeping in view the contrasting response obtained in $\mathrm{C} 4 \mathrm{crops}$ under elevated $\mathrm{CO}_{2}$, the present study was carried out with the aim to assess the impact of elevated $\mathrm{CO}_{2}$ and tropospheric $\mathrm{O}_{3}$ separately as well as in combination on the growth, yield and nutritional quality of maize under free air $\mathrm{O}_{3}$ and $\mathrm{CO}_{2}$ enrichment.

\section{MATERIALS}

\subsection{Site Description}

The experiment was carried out in free air $\mathrm{O}_{3}$ and $\mathrm{CO}_{2}$ enrichment (FAOCE) rings at the farm of Indian Agricultural Research Institute (IARI), New Delhi, India, during the summer season of 2016 and 2017 . The site is located at $\left(28^{\circ} 37^{\prime} \mathrm{N}\right.$ latitudes, $77^{\circ} 12^{\prime} \mathrm{E}$ longitudes at mean sea level of 228.6 meters in an overlap of monsoon-influenced humid subtropical and semi-arid climate with average annual precipitation of $797 \mathrm{~mm}$. The weather parameters recorded at the site are given in Table1. The experimental site had a typic Ustochrept soil, having sandy loam texture. The soil 
Table 1. Weather parameters during the crop growing seasons 2016 and 2017.

\begin{tabular}{|c|c|c|c|c|c|c|c|}
\hline \multirow{2}{*}{ Month } & \multirow{2}{*}{$\begin{array}{l}\text { Rainfall } \\
(\mathrm{mm})\end{array}$} & \multicolumn{2}{|c|}{ Average monthly temperature $\left({ }^{\circ} \mathrm{C}\right)$} & \multirow{2}{*}{$\begin{array}{l}\text { Mean } \\
\text { temperature } \\
\left({ }^{\circ} \mathrm{C}\right)\end{array}$} & \multirow{2}{*}{$\begin{array}{l}\text { Sunshine } \\
\text { (hour) }\end{array}$} & \multirow{2}{*}{$\begin{array}{l}\text { Relative } \\
\text { humidity } \\
\text { (\%) }\end{array}$} & \multirow{2}{*}{$\begin{array}{l}\text { Monthly } \\
\text { average } \mathrm{O}_{3} \\
\text { (ppb) }\end{array}$} \\
\hline & & Maximum & Minimum & & & & \\
\hline July, 2016 & 539.4 & 38.8 & 24.4 & 31.6 & 80.6 & 82 & 27.5 \\
\hline August, 2016 & 387.5 & 32.6 & 24.2 & 28.4 & 55.8 & 83 & 26.9 \\
\hline September, 2016 & 174 & 34.3 & 22.5 & 28.4 & 189.0 & 72 & 31.1 \\
\hline October, 2016 & 37.2 & 33.9 & 16.2 & 25.0 & 161.2 & 63 & 29.2 \\
\hline July, 2017 & 170.5 & 34.1 & 26.2 & 30.2 & 145.7 & 78 & 30.4 \\
\hline August, 2017 & 127.1 & 33.8 & 25.9 & 29.8 & 127.1 & 82 & 27.1 \\
\hline September, 2017 & 198 & 33.6 & 23.7 & 28.7 & 186.0 & 77 & 31.7 \\
\hline October, 2017 & 0.0 & 34.0 & 17.1 & 25.6 & 192.2 & 68 & 30.6 \\
\hline
\end{tabular}

had a total organic carbon, $\mathrm{P}, \mathrm{K}$ and total $\mathrm{N}$ content of $0.45 \%, 25.5 \mathrm{~kg} \mathrm{ha}^{-1}, 249 \mathrm{~kg} \mathrm{ha}^{-1}$ and $188 \mathrm{~kg} \mathrm{ha}^{-1}$, respectively.

\subsection{Treatment and Experiment Design}

Two maize (Zea mays L) cultivars HQPM-1 (high quality protein) and PMH-1 (normal) were sown, in free air ozone and carbon dioxide enrichment (FAOCE hereafter) rings having an area of $19.6 \mathrm{~m}^{2}$ (5.0-meter diameter) each. Four treatments were taken for the study: ambient $\mathrm{CO}_{2}$ and $\mathrm{O}_{3}(\mathrm{Amb})$, elevated $\mathrm{CO}_{2}$ and ambient $\mathrm{O}_{3}(\mathrm{EC})$, elevated $\mathrm{O}_{3}$ and ambient $\mathrm{CO}_{2}(\mathrm{EO})$ and elevated $\mathrm{CO}_{2}$ and elevated $\mathrm{O}_{3}$ (ECO). Each FAOCE ring was divided in two halves $\left(9.8 \mathrm{~m}^{2}\right)$ and each cultivar was sown in one half of the ring. There were two replicate rings for each of the four treatments. The crops were grown during 2016 and 2017 and were exposed to elevated levels of $\mathrm{O}_{3}$ and $\mathrm{CO}_{2}$ during the entire crop growth period. The targeted levels were $550 \mathrm{ppm}$ of elevated $\mathrm{CO}_{2}$ and 70 $\mathrm{ppb}$ of tropospheric $\mathrm{O}_{3}$. The ambient $\mathrm{CO}_{2}$ ranged from 388 to $416 \mathrm{ppm}$ and from 389 to $419 \mathrm{ppm}$ during 2016 and 2017 respectively. The elevated $\mathrm{CO}_{2}$ ranged from 505 to 623 ppm and from 508 to $613 \mathrm{ppm}$ in the FAOCE rings during 2016 and 2017 respectively. The wind vane and anemometer were installed in the center of the FAOCE at 1-meter height to monitor the wind direction and speed, respectively. For achieving the targeted elevated $\mathrm{CO}_{2}$ level (550 ppm), pure $\mathrm{CO}_{2}$ was released from commercial grade compressed $30 \mathrm{~kg}$ pure $\mathrm{CO}_{2}$ gas cylinders, fitted with a regulator (DURA, ESAB, India) through solenoid valves and PVC tubing to the base of each FAOCE plot with laser holes $\left(0.3 \mathrm{~mm}\right.$ diameter) at a distance of $30 \mathrm{~cm}$ to spray $\mathrm{CO}_{2}$ in the rings uniformly. Releasing of the elevated concentration of compressed $\mathrm{CO}_{2}$ was controlled by the solenoid valves as per the wind direction and speed in the FAOCE rings. $\mathrm{O}_{3}$ was produced by an ozone generator (Eltech Engineers, Mumbai) by converting atmospheric oxygen into $\mathrm{O}_{3}$ using UV lamps. Air blowers were used to mix $\mathrm{O}_{3}$ with air and the mixture of air and $\mathrm{O}_{3}$ was controlled by the flappers using solenoid valves. Air from the center of each ring was monitored for the concentrations of $\mathrm{CO}_{2}$ by using $\mathrm{C} \mathrm{CO}_{2}$ analyzer (NDIR, Topak USA) and an ozone analyzer (2B Technologies) was used for monitoring $\mathrm{O}_{3}$ levels. Microprocessors were used to perform control, logging and operation of $\mathrm{CO}_{2}$ and $\mathrm{O}_{3}$ concentrations through digital input and output modules as per wind direction and velocity on real time basis. The exposure of elevated $\mathrm{CO}_{2}$ and tropospheric $\mathrm{O}_{3}$ was given during day time (10.00 am to $17.00 \mathrm{pm}$ ) when the plant photosynthesis was taking place to save on costs as maintaining elevated $\mathrm{CO}_{2}$ was very costly. The crop was exposed to elevated tropospheric $\mathrm{O}_{3}$ for 7 hours as has been most commonly used practice in studies worldwide (Ashmore, 2005). Maize cultivars were sown on June, 24 and June, 25 in 2016 and 2017, respectively. Planting was done at $20 \mathrm{~cm}$ plant to plant and $50 \mathrm{~cm}$ row to row distances. The crops were fertilized with nitrogen ( $\mathrm{N})\left(150 \mathrm{~kg} \mathrm{ha}^{-1}\right), \mathrm{P}_{2} \mathrm{O}_{5}$, and $\mathrm{K}_{2} \mathrm{O}\left(70, \mathrm{~kg} \mathrm{ha}^{-1}\right)$ and zinc sulphate $\left(\mathrm{Zn} \mathrm{SO}_{4}\right)\left(25 \mathrm{~kg} \mathrm{ha}^{-1}\right)$. The complete doses of $\mathrm{Zn} \mathrm{SO}_{4}, \mathrm{P}_{2} \mathrm{O}_{5}$ and $\mathrm{K}_{2} \mathrm{O}$ and $50 \%$ of the nitrogen (N) were applied at the time of crop planting. The remaining amount of nitrogen was given in two equal parts at the knee high (35 DAS) and tasseling stage (65 DAS) of crop growth.

\subsection{AOT40 Calculation}

The $\mathrm{O}_{3}$ concentration during crop growth period ranged from 4 to $41.1 \mathrm{ppb}$ and from $6 \mathrm{ppb}$ to 
$38.5 \mathrm{ppb}$ in the ambient air during 2016 and 2017, respectively (Fig. 1). The elevated $\mathrm{O}_{3}$ ranged from 60 to $88 \mathrm{ppb}$ and from 55 to 87 ppb in the FAOCE rings during 2016 and 2017, respectively. The average $\mathrm{O}_{3}$ in the ambient air during crop growth period was 30.07 and $28.63 \mathrm{ppb}$ whereas average elevated $\mathrm{O}_{3}$ in the FAOCE rings was 72.75 and $71.04 \mathrm{ppb}$ during 2016 and 2017. AOT40 which is the sum of hourly average values of $\mathrm{O}_{3}$ concentration beyond $40 \mathrm{ppb}$ (Mills et al., 2018) was calculated from the elevated levels of $\mathrm{O}_{3}$ in the FAOCE rings during the complete crop growth period and was $27441 \mathrm{ppb}$ hr and $26292 \mathrm{ppb}$ hr in 2016 and 2017 respectively.

\subsection{Measurement of Plant Growth and Yield Parameters}

Leaf area index (LAI) was measured by plant canopy analyzer (LAI-2200 C) at tasseling and silking stages of crop growth. The photosynthetic rates and stomatal conductance were also measured at tasseling and at silking stages on the third leaf of the plant from the top around 11.00 am by using portable photosynthesis system (Model No. LI-6400 XT; LI-COR, USA). For evaluating yield attributes of crops, maize plants from $1 \mathrm{~m}^{2}$ area were harvested at maturity from each replicate. The cob length $(\mathrm{cm})$, cob diameter $(\mathrm{cm})$, grains number $\left(\mathrm{cob}^{-1}\right)$, grain weight $\left(\mathrm{g} \mathrm{cob}^{-1}\right)$, biological yield $\left(\mathrm{g} \mathrm{m}^{-2}\right)$, grain yield $\left(\mathrm{g} \mathrm{m}^{-2}\right)$ and 100 grain weight $(\mathrm{g})$ were determined as per standard procedures. Yield data was adjusted to $10 \%$ moisture content after drying $\left(65^{\circ} \mathrm{C}\right)$ in an oven. The ratio of grain yield and biological yield multiplied by 100 was expressed as harvest percent.

\subsection{Plant and Grain Sample Analysis}

Chlorophyll content of leaves of both the cultivars was determined at tasseling as well as silking using procedure described by Wellburn (1994). Nutritional quality parameters such as potassium (K) and phosphorus (P) were determined as per method described by Jakson (1973). The crude protein content was calculated by multiplying the conversion coefficient 5.95 with the total $\mathrm{N}$ concentration (Juliano, 1993) which was determined by the Kjeldahl method. The carbohydrate concentration of the grains was determined by the method given by Sadasivam and Minickam (1992). The lysine content of grains was estimated as per procedure described by Tsai et al. (1972). The amylose content was determined by procedure described by Hu et al. (2010).

\subsection{Statistical Analysis}

Using the 9.3 SAS statistical software, growth, yield, yield components and quality attributes of maize were analyzed. Split plot design was used to conduct the experiment. Two-way analysis of variance (ANOVA) was used to analyze the impact of cultivar and the four treatments. The statistically significance of data was compared based on their $95 \%$ confidence level $(p<0.05)$ (Gomez and Gomez, 1984).

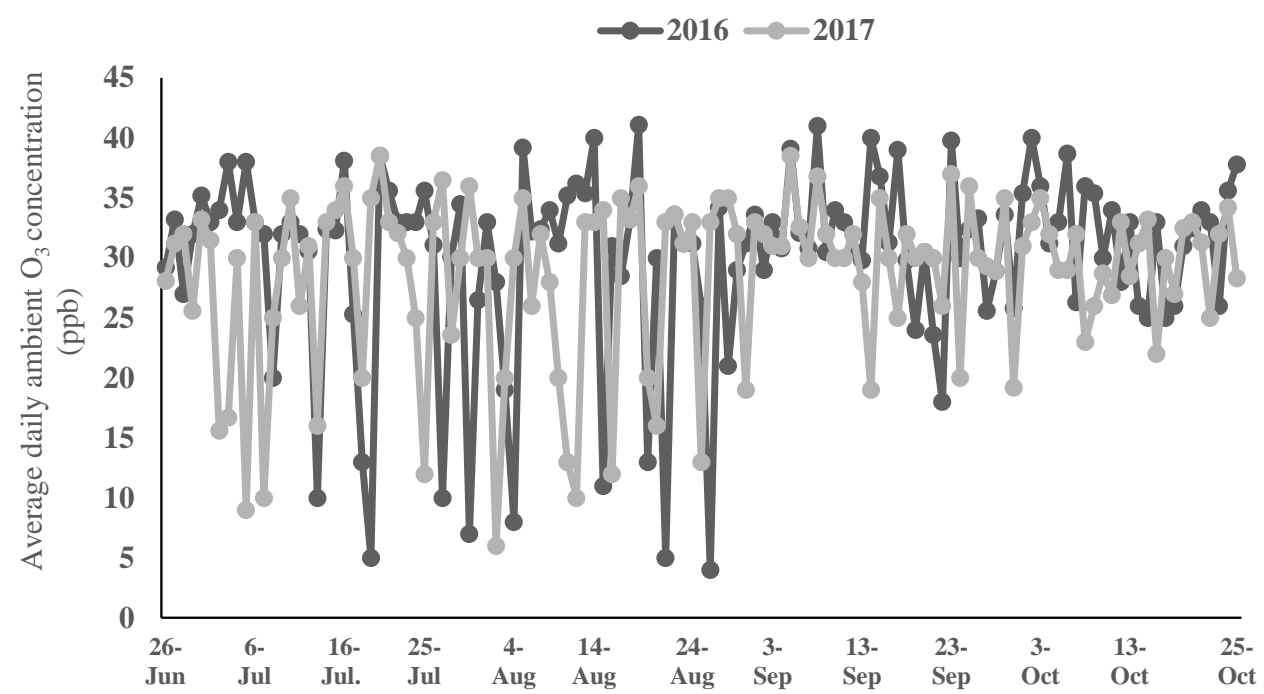

Fig. 1. The concentrations of daily average ambient $O_{3}$ during 2016 and 2017. 


\subsection{Impact of Elevated $\mathrm{CO}_{2}$ and $\mathrm{O}_{3}$ on Photosynthetic Rate, Stomatal Conductance, Chlorophyll Content and Leaf Area Index}

The mean photosynthetic rates $(\mathrm{Pn})$ ranged from 33-34.8 $\mu$ mole $\mathrm{CO}_{2} \mathrm{~m}^{-2} \mathrm{~s}^{-1}$ under $\mathrm{EO}$ and from 41.8-44.4 $\mu$ mole $\mathrm{CO}_{2} \mathrm{~m}^{-2} \mathrm{~s}^{-1}$ under EC across the crop growth stages and cultivars. It increased significantly by $12.1-16.6 \%$ ( $p<0.05)$ in HQPM-1 and by $12.4-15.5 \%(p<0.05)$ in PMH-1 under EC treatment across the crop growth stages in the two years (average data) (Table 2). However, increased tropospheric $\mathrm{O}_{3}$ (EO) significantly reduced the Pn of HQPM-1 (7.8-9.4\%) and PMH-1 $(6.7-15.4 \%)(p<0.05)$ (Table 2) at both crop stages as compared to the ambient. The $\mathrm{Pn}$ in the interactive treatment ECO increased by $11.9-12.4 \%$ for HQPM-1 and by $10.9-18.5 \%$ for PMH-1 (across the stages) over elevated $\mathrm{O}_{3}$ alone and was found to be at par with the ambient.

The stomatal conductance $(g s)$ significantly decreased $(p<0.01)$ in both the cultivars under EC, EO and ECO as compared to the ambient (Table 2). The lowest gs was observed in EC treatment at tasseling stage in $\mathrm{PMH}-1$ cultivar.

Similar to the Pn the total chlorophyll content of leaves increased under EC and reduced under EO as compared to the ambient in both the cultivars (Table 2). In the ECO treatment, elevated $\mathrm{CO}_{2}$ negated the effect of $\mathrm{O}_{3}$ on the chlorophyll content in HQPM-1 (9.8-11\%) and PMH-1 (4.8$10.4 \%$ ) over elevated $\mathrm{O}_{3}$ alone.

Significant difference in LAI was observed between the cultivars. Increased concentration of EO led to a higher decline in LAI of HQPM-1 (13.2-16.2\%) as compared to PMH-1 (7.5-8.5\%) at tasseling and silking stages. Under ECO, a higher increase in LAI was observed for HQPM-1 (12.1$16.1 \%)$ as compared to PMH-1 (5.4-8.5 \% in PMH-1) over EO across the years and stages.

\subsection{Impact of Elevated $\mathrm{CO}_{2}$ and $\mathrm{O}_{3}$ on Yield Components}

The cob length $(\mathrm{cm})$ and grains $\left(\mathrm{cob}^{-1}\right)$ reduced in both cultivars under EO. Elevated $\mathrm{CO}_{2}$ significantly $(p<0.01)$ increased the cob length as well as grains $\left(\mathrm{cob}^{-1}\right)$ in both crop cultivars as compared to the ambient (Amb). Under the interactive treatment (ECO) averaged cob length increased by $9.4 \%$ for HQPM-1 and by $5.8 \%$ for $\mathrm{PMH}-1$ over EO alone and was found to be at par with the Amb (Table 3). Average grain weight ( $\mathrm{cob}^{-1}$ ) under EC significantly increased in HQPM-1 (22.1\%)- and in PMH-1 (5.32\% (Table 3). While, EO reduced the grain weight $\left(\mathrm{cob}^{-1}\right)$ by $5.8 \%$ in HQPM-1 and by $11.3 \%$ in PMH-1 as compared to the Amb (Table 3). Under the interactive treatment ECO grain weight $\left(\mathrm{cob}^{-1}\right)$ increased by $12.2 \%$ in HQPM-1 as compared to EO alone, whereas there was no significant difference in $\mathrm{PMH}-1$. The 100 grain weights of HQPM-1 and $\mathrm{PMH} 1$ were not-significantly different under ECO treatment as compared to the ambient during both the years.

Grain yield of HQPM-1 increased significantly in the first $(33.3 \%, p<0.01)$ and the second year $(17.4 \%, p<0.01)$ under EC as compared to the Amb. Similarly, grain yield of PMH-1 responded positively to the increased $\mathrm{CO}_{2}$ during the first $(10.5 \%)(\mathrm{p}<0.01)$ and the second year $(7.5 \%)$ (Table 3 ). Under the interactive treatment ECO, averaged grain yield increased by $18.8 \%$ in HQPM-1 and by $11.2 \%$ in $\mathrm{PMH}-1$ as compared to the elevated $\mathrm{O}_{3}$ alone.

\subsection{Impact of Elevated $\mathrm{CO}_{2}$ and $\mathrm{O}_{3}$ on Quality of the Grains}

The mean of the two years' data revealed that the elevated $\mathrm{CO}_{2}$ concentration in free air declined the crude protein by $8.1 \%$ in HQPM-1 and by $12.5 \%$ in $\mathrm{PMH}-1$. On the contrary, the enrichment of $\mathrm{O}_{3}$ increased the crude protein significantly $(\mathrm{p}<0.05)$ by $13.5 \%$ in HQPM-1 and by 13.4\% in PMH-1 as compared to the ambient (Fig. 2(a)). The EC treatment diminished the positive influence of elevated $\mathrm{O}_{3}$ on protein concentration and it decreased by 8.2 and $8.8 \%$ for HQPM-1 and $\mathrm{PMH}-1$, respectively under the ECO treatment as compared to EO alone. The protein contents in both the crop cultivars under the interactive treatment (ECO) were at par with the Amb (Fig. 2(a)).

Carbohydrate content of grains increased in HQPM-1 (4.6\%) and PMH-1 (15.5\%) under the EC, but responded negatively to EO in HQPM-1 (15.3\%) and PMH-1 (16.6\%) as compared to the ambient treatment (Fig. 2(b)). No significant change was obtained in the carbohydrate content 

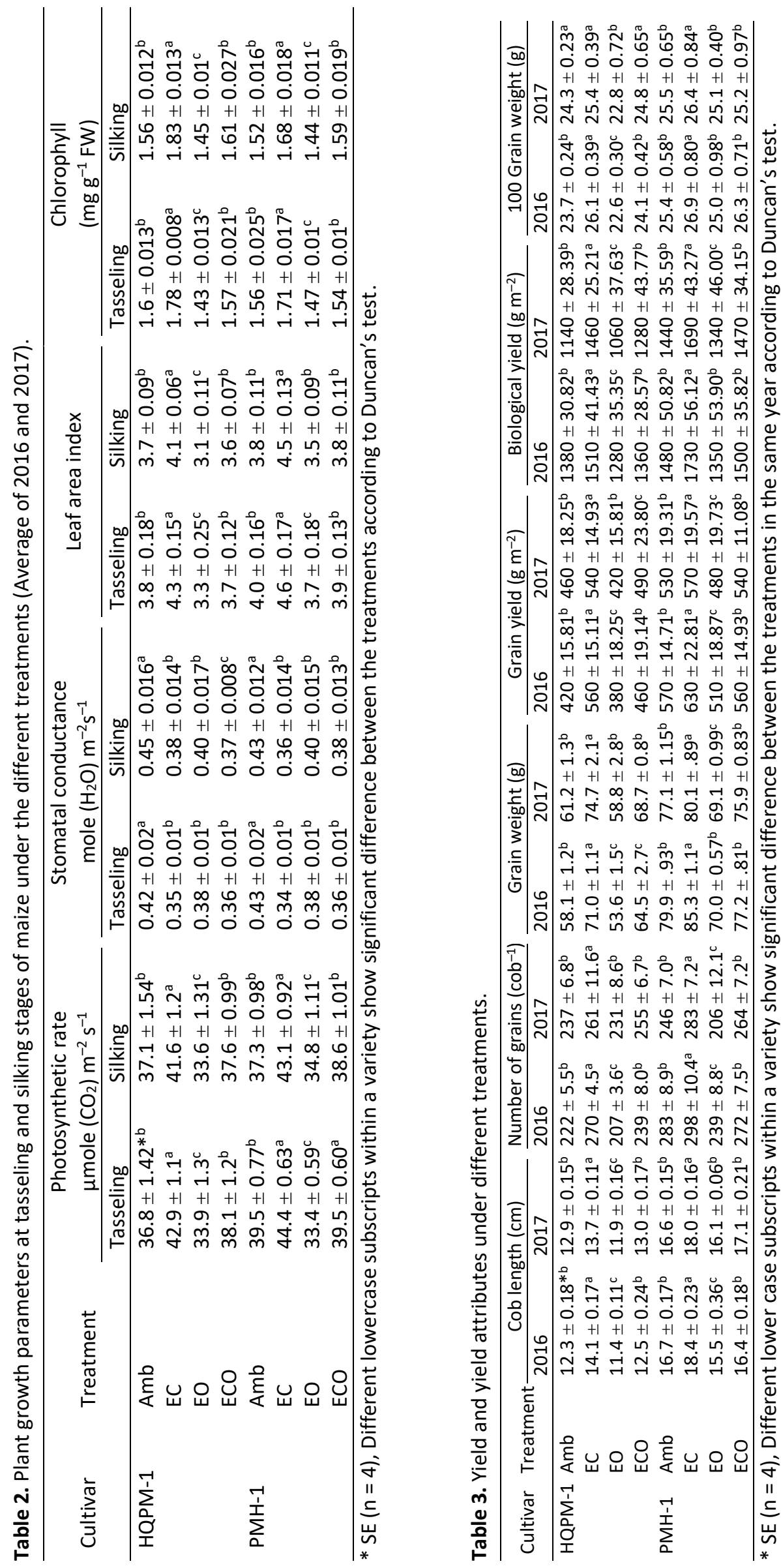


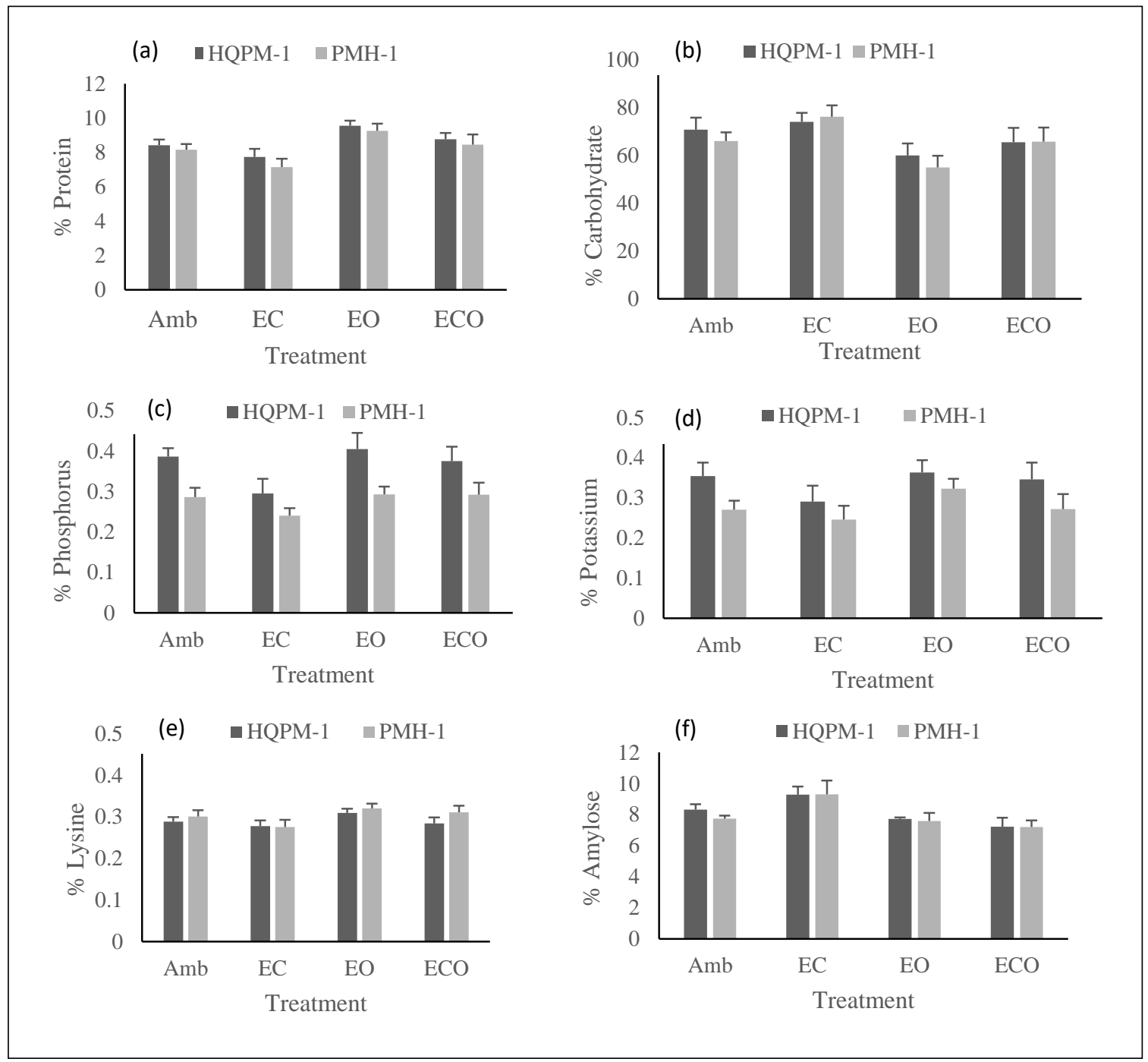

Fig. 2. (a) Protein (b) carbohydrate (c) phosphorus (d) potassium (e) lysine and (f) amylose content in maize grains under the different treatments (Average of 2016 and 2017).

in maize grains under ECO in both the cultivars as compared to the Amb. Phosphorus (P) (16.2$23.6 \%$ ) and potassium (K) (8.9-17.3\%) concentrations significantly decreased $(p<0.01)$ under elevated $\mathrm{CO}_{2}$ treatment in both the cultivars as compared to the Amb (Table 4(c)). However, P (2.3$4.9 \%)$ and $\mathrm{K}(2.5-19.3 \%)$ increased under elevated tropospheric $\mathrm{O}_{3}$. The interactive environment under ECO did not lead to any change in the $\mathrm{P}$ and $\mathrm{K}$ concentrations of grains as compared to the ambient (Figs. 2(c) and 2(d)). The amylose content also varied similar to the carbohydrate content of grains in the different treatments (Fig. 2(f)).

Lysine is an important $\alpha$ amino acid that is needed for the biosynthesis of proteins. It ranged under from 0.30 to $0.32 \%$ under elevated $\mathrm{O}_{3}$ (EO) and from 0.27 to $0.28 \%$ under elevated $\mathrm{CO}_{2}$ (EC). Lysine contents of maize grains decreased under EC by $3.7-8.4 \%$ and increased by $6.5-7.3 \%$ under EO over the ambient treatment in both HQPM-1 and PMH-1 maize cultivars (Fig. 2(e)).

\subsection{Varietal Response to Yield and Quality under Different Treatments}

During the first year AOT 40 of $27741 \mathrm{ppb} \mathrm{hr}$ of $\mathrm{O}_{3}$ exposure led to decline in grain yield in HQPM-1 by $9.5 \%$, and by $15.7 \%$ \% in PMH-1, while during the second year AOT exposure of 26292 $\mathrm{ppb} \mathrm{hr}$, decreased the grain yield of HQPM-1 by $8.7 \%$ and by $3.8 \%$ in $\mathrm{PMH}-1$. On an average the exposure of $\mathrm{AOT} 4 \mathrm{O}$ of 27016-ppbhr $\mathrm{O}_{3}$ led to the yield loss of 9.2\% in HQPM1 and 9.8\% in PMH1 during the two years of the study. Under EC there was higher increase in grain yield of HQPM-1 as compared to PMH-1. Under ECO the grain yield of HQPM-1 increased by (6.5-9.5\%) over ambient 
but in case of PMH-1 it was not significantly different than ambient during the two years. There was higher increase in biological yield under EC in HQPM-1 (11.4-28\%) as compared to PMH-1 $(15.9-17.3 \%)$ ( $p<0.05)$ during the two years as compared to the Amb. The increase in grain number $\mathrm{cob}^{-1}$ under elevated $\mathrm{CO}_{2}$ was higher for HQPM-1 (10.1-21.6\%) as compared to $\mathrm{PMH}-1$ $(5.3-15 \%)(p<0.05)$ over Amb. Under the interactive treatment ECO grain weight $\mathrm{cob}^{-1}$ increased by $12.2 \%$ in HQPM-1 as compared to EO alone, whereas there was no significant difference in $\mathrm{PMH}$ 1. No significant difference in protein, carbohydrate, $\mathrm{P}$ and $\mathrm{K}$ content was observed under ECO treatment as compared to Amb in any of the crop cultivars (Fig. 2).

\section{DISCUSSIONS}

Present study was carried out under free air field condition to study the responses of two varieties of maize, grown under elevated levels of tropospheric $\mathrm{O}_{3}$ and $\mathrm{CO}_{2}$ individually as well as in combination. Due to low humidity, high light intensity, and high temperature in the IndoGangetic Plains (IGP) there are high concentrations of tropospheric $\mathrm{O}_{3}$ along with atmospheric $\mathrm{CO}_{2}$ (IPCC, 2014; Mills et al., 2018) in this region. Leakey et al. (2009) reported that $\mathrm{C}_{4}$ crops under elevated $\mathrm{CO}_{2}$ did not increase the photosynthetic rate directly and only stimulated the uptake of carbon during drought or at midday when short-term water stress developed under high atmospheric vapour pressure deficits and temperatures in temperate climatic conditions. However, our results and also those of Abebe et al. (2016) and Pingale et al. (2017) confirmed that the elevated $\mathrm{CO}_{2}$ increased $\mathrm{Pn}$ of maize grown under tropical semi-arid environment. Higher daytime temperatures in tropical conditions, may result in higher vapour pressure deficit resulting in short term water stress, thereby increasing the $\mathrm{CO}_{2}$ uptake even in $\mathrm{C}_{4}$ maize.

EO significantly reduced the photosynthetic rate in both the crop cultivars and that might be due to entering of $\mathrm{O}_{3}$ molecules through stomatal pores during normal gas exchange process that created the reactive oxygen species (ROS), which may lead to programmed cell death (McGrath et al., 2015; Yendrek et al., 2017). No significant change in photosynthetic rate was observed under the interactive treatment (ECO) over the ambient (Amb), which could be due to reduced penetration of higher concentration of $\mathrm{CO}_{2}$ and tropospheric $\mathrm{O}_{3}$ through the stomata (Table 4(a)), because elevated $\mathrm{CO}_{2}$ andO $\mathrm{O}_{3}$ both prohibit the opening of stomatal pores of the leaves, that minimize $\mathrm{O}_{3}$ flux in plant apoplast (Oikawa and Ainsworth, 2016). EC and EO conditions significantly reduced the $g s$ in both crop varieties, and it might be attributed to reduced stomatal density and less opening of the stomatal pores (Xu et al., 2016; Singh et al., 2018). In previous research it was documented that $g s$ reduced under $\mathrm{CO}_{2}$ condition in $\mathrm{C}_{4}$ crops (Harley and Baldocchi, 1995; De Souza et al., 2015; Hoshika et al., 2015). However, $\mathrm{O}_{3}$ induced damage may be less for $\mathrm{C}_{4}$ species, given their intrinsically lower stomatal conductance, as well as for plants under rising $\mathrm{CO}_{2}$ (McGrath et al., 2015).

Leaf area index and chlorophyll content of leaves were also significantly impacted under the different treatments however, the cultivar treatment interaction was not significantly different at both the crop stages (Table 4(a)). Adishesha et al. (2017) reported that the chlorophyll content of maize increased under elevated $\mathrm{CO}_{2}$ environment and reduced under the tropospheric $\mathrm{O}_{3}$ concentration (Bhatia et al., 2014). Deterioration in chlorophyll content of leaves under EO might be because of damage to the chloroplast due to change in membrane permeability (Zhu et al., 2011). EC (550 ppm) and EO (70 ppb) treatment significantly $(p<0.01)$ impacted the crop yield parameters such as cob length, grains $\left(\mathrm{cob}^{-1}\right)$, biological yield and grain yield (Table $\left.4(b)\right)$. The cultivar * treatment interaction did not significantly impact crop yield components except cob length and 100 grain weights (Table 4(b)). Higher grain number $\left(\mathrm{cob}^{-1}\right)$ and cob length $(\mathrm{cm})$ of HQPM-1 by $11.5 \%$ and $9.7 \%$, respectively in the first year as compared to the second year resulted in higher grain yield in the first year. Improvement in the biological yield and grain yield of cultivars under EC condition was due to the increased photosynthetic rate (12.1-16.6\%), cob length (9.3$10.4 \%)$, number of grains $\left(\mathrm{cob}^{-1}\right)(10.2-15.8 \%)$ and test weight. In previous studies it was reported that cob length, grains $\left(\mathrm{cob}^{-1}\right)$, biological yield and 100 grain weights increased significantly under the EC and vice-versa in the EO condition (Singh et al., 2014; Ainsworth, 2017). Basu et al. (2014) assessed the responses of 23 maize simulation models and concluded that the doubling of $\mathrm{CO}_{2}$ from 360 to 720 ppm would increase grain yield by $7.5 \%$ on an average across the sites. 
Table 4. (a) F-ratio and level of significance for plant growth parameters at tasseling and silking. (b) F -ratio and level of significance for maize yield and yield attributes. (c) $\mathrm{F}$-ratio and level of significance for maize quality attributes.

(a)

\begin{tabular}{|c|c|c|c|c|c|c|}
\hline \multirow{2}{*}{ Parameter } & \multicolumn{3}{|c|}{ Tasseling } & \multicolumn{3}{|c|}{ Silking } \\
\hline & Cultivar & Treatment & Cultivar $\times$ Treat & Cultivar & Treatment & Cultivar $\times$ Treat \\
\hline Photosynthetic rate & $0.003 n s$ & $2.79 *$ & $0.77 n s$ & $0.03 n s$ & $44.56 * *$ & $0.28 \mathrm{~ns}$ \\
\hline Stomatal conductance & $9.85^{*}$ & $30.95 * *$ & $2.01 \mathrm{~ns}$ & $8.11^{*}$ & $26.76^{* *}$ & $1.76 \mathrm{~ns}$ \\
\hline LAI & $10.25^{*}$ & $21.20 * *$ & $1.91 \mathrm{~ns}$ & $13.33^{*}$ & $31.77^{* *}$ & $2.22 \mathrm{~ns}$ \\
\hline Chlorophyll & $0.20 \mathrm{~ns}$ & $52.11 * *$ & $0.29 \mathrm{~ns}$ & $0.34 \mathrm{~ns}$ & $48.9 * *$ & $0.29 \mathrm{~ns}$ \\
\hline
\end{tabular}

* significant at $0.05, * *$ significant at 0.01 level, and ns = non-significant.

(b)

\begin{tabular}{llllllll}
\hline Parameter & Year & Cultivar & Treatment & Year $\times$ Cultivar & Year $\times$ Treat. & Cultivar $\times$ Treat. & $\begin{array}{l}\text { Year } \times \text { Cultivar } \times \\
\text { Treat. }\end{array}$ \\
\hline Cob length & $47.28^{* *}$ & $7.46^{* *}$ & $105.73^{* *}$ & $0.217 \mathrm{~ns}$ & $0.62^{\mathrm{ns}}$ & $5.68^{*}$ & $1.12^{\mathrm{ns}}$ \\
Grains $\left(\mathrm{cob}^{-1}\right)$ & $35.19^{* *}$ & $1.61^{\mathrm{ns}}$ & $44.03^{* *}$ & $18.23^{*}$ & $3.86^{*}$ & $1.12^{\mathrm{ns}}$ & $2.71^{\mathrm{ns}}$ \\
Grain weight $\left(\mathrm{cob}^{-1}\right)$ & $72.99^{* *}$ & $17.12^{* *}$ & $292.88^{* *}$ & $13.06^{*}$ & $8.27^{*}$ & $3.86^{*}$ & $10.13^{* *}$ \\
Grain yield & $13.27^{*}$ & $0.35^{\mathrm{ns}}$ & $71.91^{* *}$ & $3.93^{*}$ & $2.74^{\mathrm{ns}}$ & $1.30^{\mathrm{ns}}$ & $0.247^{\mathrm{ns}}$ \\
Biological yield & $20.10^{*}$ & $32.46^{* *}$ & $112.01^{* *}$ & $28.34^{*}$ & $3.41^{*}$ & $0.73^{\text {ns }}$ & $0.031^{\mathrm{ns}}$ \\
100 grain weight & $8.49^{*}$ & $5.15^{*}$ & $23.1^{* *}$ & $9.95^{*}$ & $0.96^{\mathrm{ns}}$ & $4.71^{*}$ & $2.95^{*}$ \\
\hline
\end{tabular}

* significant at $0.05, * *$ significant at 0.01 level, and ns = non-significant.

(c)

\begin{tabular}{llll}
\hline Element & Cultivar & Treatment & Cultivar $\times$ Treat. \\
\hline Protein & $9.22^{*}$ & $11.72^{*}$ & $2.44^{\mathrm{ns}}$ \\
Carbohydrate & $11.03^{*}$ & $23.45^{*}$ & $2.11^{\mathrm{ns}}$ \\
Phosphorus & $66.86^{* *}$ & $16.71^{* *}$ & $1.65^{\mathrm{ns}}$ \\
Potassium & $47.18^{* *}$ & $17.34^{* *}$ & $2.23^{\mathrm{ns}}$ \\
Lysine & $1.22^{\mathrm{ns}}$ & $17.61^{*}$ & $1.99^{\mathrm{ns}}$ \\
Amylose & $0.84^{\mathrm{ns}}$ & $22.46^{* *}$ & $0.53^{\mathrm{ns}}$ \\
\hline
\end{tabular}

* significant at $0.05, * *$ significant at 0.01 level, and ns $=$ non-significant.

The fumigation of elevated $\mathrm{O}_{3}$ throughout the plant growth, reduced photosynthetic rate, grain weight ( $\left.\mathrm{cob}^{-1}\right)$, cob length, grains $\left(\mathrm{cob}^{-1}\right)$ and 100 grain weight of crop cultivars and led to reduced grain yield in the EO treatment. It may be attributed to the entry of $\mathrm{O}_{3}$ molecules in plants through leaf stomata and its quick reaction with the molecules of the intercellular space and production of reactive oxygen species (ROS) in the apoplast (Ainsworth, 2017). The produced ROS in apoplast trigger metabolic defense mechanism and causing programme cell death that promote leaf senescence, resulting in diversion of resources during growth and seed production and ultimately influences the crop yield. Feng et al. (2015) and Leisner and Ainsworth (2012) observed that the elevated tropospheric $\mathrm{O}_{3}$ damages the crop during the reproductive stage of growth due to increased abiotic stress sensitivity and high demand of resources for seed development. In our study the physiological maturity was reached earlier by 4 days under the EO treatment in both the crop cultivars, and it was delayed by five days in the elevated $\mathrm{CO}_{2}$ treatment as compared to the ambient and this may have contributed to the decrease or increase in maize yield under EO and EC respectively. Similar to our findings Broberg et al. (2015) and Pleijel et al. (2015) pointed out that the senescence promoted the negative effects of tropospheric $\mathrm{O}_{3}$ on the duration of grain filling, resulting in lower grain mass of wheat and reduced yield.

An increase in grain yield of maize was observed under the interactive treatment ECO over the ambient, implying that $559 \mathrm{ppm}$ of elevated $\mathrm{CO}_{2}$ was able to offset the negative impact of elevated $\mathrm{O}_{3}(71 \mathrm{ppb})$ on the grain yield. The mitigative effect of $\mathrm{EC}$ under the combined interactive treatment may be attributed to the reduced stomatal conductance and declined stomatal density which reduced the influx of $\mathrm{O}_{3}$ into the plant leaves (Gray et al., 2000; Ainsworth et al., 2008).

Besides, impacts on growth and grain yield, elevated carbon dioxide (EC) and elevated tropospheric (EO) also impacted quality of grains. In this study phosphorus (P), potassium (K), 
protein and lysine reduced under EC and increased under EO (Table 4(c)). However, carbohydrate and amylose contents of grains increased under EC but reduced under EO treatment in both the maize varieties. In our study the average photosynthetic rates (12.1-16.6\%) of crop cultivars under EC was more compared to the Amb, which might have caused improved carbohydrate accumulation in the plants, resulting in dilution of $P, K$, protein and lysine concentrations under EC treatment and vice versa under EO. No significant interaction could be observed between the cultivars and the treatments (Table 4(c)). It has been reported in other crops that the concentration of $\mathrm{P}, \mathrm{K}$ and crude protein of the grains reduced significantly under the elevated $\mathrm{CO}_{2}$ and increased under elevated $\mathrm{O}_{3}$ (Hogy et al., 2009; Zhang et al., 2013; Zhou et al., 2015; Zhu et al., 2018). Mishra et al. (2013) noticed a negative correlation between grain yield and grain protein content due to the growth dilution effect.

The average decline in yield over the two years under elevated $\mathrm{O}_{3}$ in both the cultivars was similar, however they responded differently to elevated $\mathrm{CO}_{2}$. The increase in grain yield was more in HQPM1 as compared to PMH-1 under EC treatment. Thus, under the interaction ECO the offsetting of grain yield as compared to decline in yield due to EO was much higher in case of HQPM-1. The increase in grain yield was higher in HQPM-1 under EC due to higher increase in 100 grain weight. The differences obtained in the grain weights $\left(\mathrm{cob}^{-1}\right)$ of crop cultivars under various treatment was due to the number of grains $\left(\mathrm{cob}^{-1}\right)$ and 100 grain weight $(\mathrm{g})$.

\section{CONCLUSIONS}

In our study the presence of elevated $\mathrm{CO}_{2}$ increased the carbon uptake and yield of maize, but the increased carbohydrates in the grain led to a decline in the nutrient content $(P, K \&$ crude protein) due to the dilution effect and lowered the grain quality. Just the opposite was observed under elevated $\mathrm{O}_{3}$. The elevated $\mathrm{CO}_{2}$ mitigated the adverse impacts of elevated $\mathrm{O}_{3}$ on the maize growth and yield under the interaction treatment. After two years of study we could conclude that elevated $\mathrm{CO}_{2}(559 \mathrm{ppm})$ was able to offset the negative effect of elevated $\mathrm{O}_{3}(71 \mathrm{ppb})$ on growth parameters (4.8-18.3\%) and yield (11.2-18.8\%) without significantly affecting the grain quality in both the maize cultivars. This amelioration was primarily due to a reduction in stomatal conductance, as a consequence of $\mathrm{CO}_{2}$ elevation. The yield and the grain nutrient content of maize grown under the interaction of elevated $\mathrm{CO}_{2}$ and $\mathrm{O}_{3}$ (ECO) was observed to be at par with the ambient. Therefore, the yield and nutrient content of maize would be the least affected under the future climatic scenario of increasing atmospheric $\mathrm{CO}_{2}$ and $\mathrm{O}_{3}$ concentrations in tropical environments.

\section{ACKNOWLEDGEMENTS}

Authors thank the School of Environmental Sciences, Jawaharlal Nehru University, New Delhi and Director, ICAR- Indian Agricultural Research Institute, New Delhi for providing the facilities to execute the experimental work. Authors acknowledge the funding support provided by the NICRA project, ICAR, GOI for carrying out this research. Authors also extend their sincere thanks to Dr. S.D. Singh, Dr. Bidisha Chakrabarti, Mr. Raghuveer and Miss Abhilasha for help and guidance during the experiment.

\section{REFERENCES}

Abebe, A., Pathak, H., Singh, S.D., Bhatia, A., Harit, R., Kumar, V. (2016). Growth, yield and quality of maize with elevated atmospheric carbon dioxide and temperature in North West India. Agric. Ecosyst. Environ. 218, 66-72. https://doi.org/10.1016/j.agee.2015.11.014

Adishesha, K., Janagoudar, B.S., Amaregouda, A. (2017). Response of maize (Zea mays L.) genotypes to elevated carbon dioxide and temperature regimes. Int. J. Chem. Stud. 5, 24482256. https://www.chemijournal.com/archives/2017/vol5issue5/PartAG/5-5-421-234.pdf

Ainsworth, E.A. (2008). Rice production in a changing climate: a meta-analysis of responses to elevated carbon dioxide and elevated ozone concentration. Global Change Biol. 14, 1642- 
1650. https://doi.org/10.1111/j.1365-2486.2008.01594.x

Ainsworth, E.A. (2017). Understanding and improving global crop responses to ozone. Plant J. 90, 886-897. https://doi.org/10.1111/tpj.13298

Ashmore, M.R. (2005). Assessing the future global impacts of ozone on vegetation. Plant Cell Environ. 28, 949-964. https://doi.org/10.1111/j.1365-3040.2005.01341.x

Basu, S., Brisson, N., Durand, D.L., Boote, K., Lizaso, J., Jones, J.W., Rosenzweig, C.,Ruane, A.C., Adam, M.,Baron, C., Baso, B., Biernath, C., Boogaard,H.,Conijn, S., Corbeels, M., Deryng, D., De Sanctis, G., Gayler, S., Grassini, P., ... Waha, K. (2014). How do various maize crop models vary their responses to climate change factors? Global Change Biol. 20, 2301-2320. https://doi.org/10.1111/gcb.12520

Bhatia, A., Ghosh, A., Kumar, V., Tomer, R., Singh, S.D., Pathak, H. (2011). Effect of elevated tropospheric ozone on methane and nitrous oxide emission from rice soil in North India. Agric. Ecosyst. Environ. 144, 21-28. https://doi.org/10.1016/j.agee.2011.07.003

Bhatia, A., Tomer, R., Kumar, V., Singh, S.D., Pathak, H. (2012). Impact of tropospheric ozone on crop growth and productivity - A review. J. Sci. Ind. Res. 71, 97-112. http://nopr.niscair.res.in/ handle/123456789/13486

Bhatia, A., Kumar, V., Kumar, Amit. and Singh, S.D. (2014). Effect of elevated ozone and carbon dioxide interaction on growth and yield of maize. Maydica 58, 291-98. https://journalscrea.4science.it/index.php/maydica/article/view/957/817

Broberg, M.C., Feng, Z., Xin, Y., Pleijel, H. (2015). Ozone effects on wheat grain quality - A summary. Environ. Pollut. 197, 203-213. https://doi.org/10.1016/j.envpol.2014.12.009

Broberg, M.C., Uddling, J.M.G., Peijel, H. (2017). Fertilizer efficiency in wheat is reduced by ozone pollution. Sci. Total Environ. 607-608, 876-880. https://doi.org/10.1016/j.scitotenv.2017.07.069

De Souza, A.P., Cocuron, J.C., Garcia, A.C., Alonso, A.P., Buckeridge, M.S. (2015). Changes in whole-plant metabolism during the grain-filling stage in sorghum grown under elevated $\mathrm{CO}_{2}$ and drought. Plant Physiol. 169, 1755-1765. https://doi.org/10.1104/pp.15.01054

European Environment Agency (EEA) (2000). http://glossary.eea.europa.eu/EEAGlossary

Feng, Z., Hu, E., Wang, X., Jiang, L., Liu, X. (2015). Ground-level $\mathrm{O}_{3}$ pollution and its impacts on food crops in China: A review. Environ. Pollut. 199, 42-48. https://doi.org/10.1016/j.envpol.2 015.01 .016

Food and Agriculture Organization (FAO) (2016). Agricultural data. Food and Agriculture Organization of The United Nations, Rome, http://faostat.fao.org/

Frei, M. (2015). Breeding of ozone resistant rice: Relevance, approaches and challenges. Environ. Pollut. 197, 144-155. https://doi.org/10.1016/j.envpol.2014.12.011

Gomez, K.A., Gomez A. (1984). Statistical Procedure for Agricultural Research 2nd ed. Willey New York, USA, p. 704.

Government of India (2017). Chapter 7: Agriculture and Food Management. in Economic Survey 2016-17, Economic Survey - Volume II, Ministry of Finance, Government of India. https://www.indiabudget.gov.in/budget2017-2018/es2016-17/echap07_vol2.pdf

Gray, J.F., Holroyd, G.H., Van Der Lee, F.M., Ahrami, A.R., Sijmons, P.C., Woodward, F.I., Schuch, W., Hetherington, AM. (2000). The III C signaling pathway links $\mathrm{CO}_{2}$ perception to stomatal development. Nature 408, 713-716. https://doi.org/10.1038/35047071

Harley, P.C., Baldocchi, D.D. (1995). Scaling carbon dioxide and water vapour exchange from leaf to canopy in a deciduous forest. I. Leaf model parametrization. Plant Cell Environ. 18, 11461156. https://doi.org/10.1111/j.1365-3040.1995.tb00625.x

Hogy, P., Weiser, H., Kohler, P., Schwadorf, K., Breuer, J., Muntifering, R., Fangmeir, A. (2009). Effect of elevated $\mathrm{CO}_{2}$ on grain yield and quality of wheat: Results from 3-yearfree air $\mathrm{CO}_{2}$ experiment. Plant Biol. 11, 60-69. https://doi.org/10.1111/j.1438-8677.2009.00230.x

Hoshika, Y., Katata, G., Deushi, M., Watanabe, M., Koike, T., Paoletti, E. (2015). Ozone induced stomatal sluggishness changes carbon and water balance of temperate deciduous forests. Sci. Rep. 5, 9871. https://doi.org/10.1038/srep09871

Hu, G., Burton, C., Yang, C. (2010). Efficient measurement of amylose content in cereal grains. J. Cereal Sci. 51, 35-40. https://doi.org/10.1016/j.jcs.2009.08.007

IPCC (2014). Climate Change. 2014. Impacts, adaptation and vulnerability. Contribution of Working Group II to the Fifth Assessment Report of the Intergovernmental Panel on Climate Change. Cambridge University Press, Cambridge, United Kingdom and New York. NY, USA. 
https://www.ipcc.ch/report/ar5/wg2/

Jackson, M.L. (1973). Soil chemical analysis. Prentice. Hall of India, New Delhi, pp. 219-221.

Juliano, B.O. (1993). Rice in human nutrition, FAO Food and Nutrition Series, No. 26, International Rice Research Institute, Los Baños, Philippines.

Kumari, S., Agrawal, M., Singh, A. (2015). Effects of ambient and elevated $\mathrm{CO}_{2}$ and ozone on physiological characteristics, antioxidative defense system and metabolites of potato in relation to ozone flux. Environ. Exp. Bot. 109, 276-287. https://doi.org/10.1016/j.envexpbot.2 014.06.015

Leakey, A.D.B., Uribelarrea, M., Ainsworth, E.A., Naidu, S.L., Rogers, A., Ort, D.R., Long S.P. (2006). Photosynthesis productivity and yield of maize are not affected by open -air -elevation of $\mathrm{CO}_{2}$ concentration in the absence of drought. Plant Physiol. 140, 779-790. https://doi.org/10.110 4/pp.105.073957

Leakey, A.D.B. (2009). Rising atmospheric carbon dioxide concentration and the future of $\mathrm{C}_{4}$ crops for food and fuel. Proc. R. Soc. London, Ser. B 276, 2333-2343. https://doi.org/10.1098/rspb.2 008.1517

Leisner, C.P., Ainworth, E.A. (2012). Quantifying the effects of ozone on plant reproductive growth and development. Global Change Biol. 18, 606-616. https://doi.org/10.1111/j.13652486.2011.02535.x

Lopes, A., Ferreira, A.B., Pantoja, P.O., Parolin, P., Premade, M.T.F. (2018). Combined effect of elevated $\mathrm{CO}_{2}$ level and temperature on germination and initial growth of Montrichardia arborescens (L.) Schott (Araceae): A microcosm experiment. Hydrobiol 814, 19-30. https://doi.org/10.1007/s10750-015-2598-1

McGrath, J.M., Betzelberger, A.M., Wang, S., Shook, E., Zhu, X.G., Long, S.P., Ainsworth, E.A. (2015). An analysis of ozone damage to historical maize and soybean yields in the United States. Proc. NatI. Acad. Sci. U.S.A. 112, 14390-14395. https://doi.org/10.1073/pnas.1509777 112

Mills, G., Sharps, K., Simpson, D., Pleijel, H., Broberg, M., Uddling, J., Jaramillo, F., Davies, W.J., Agrawal, M., Agrawa,I S.B., Ainsworth, E.A.,Buker, P., Dentener, F., Emberson, L., Feng, Z., Harmens, H., Hayes, F., Kobayashi, K., Paoletti, E., Van den Berg, M., Van, D.R. (2018). Ozone pollution will compromise efforts to increase global wheat production. Global Change Biol. 24 3560-3574. https://doi.org/10.1111/gcb.14157

Mishra, A.K., Rai, R., Agrawal, S.B. (2013). Differential response of dwarf and tall tropical wheat cultivars to elevated ozone with and without carbon dioxide enrichment: Growth, yield and rain quality. Field Crops Res. 145, 21-32. https://doi.org/10.1016/j.fcr.2013.02.007

Myers, S.S., Zanobetti, A., Kloog, I., Huybers, P., Leakey, A.D.B., Bloom, A.J., Carlisle, E., Dietterich, L.H., Fitzgerald, G., Hasegawa, T., Holbrook, N.M., Nelson, R.L., Ottman, M.J., Raboy, V., Sakai, H., Sartor, K.A., Schwartz, J., Seneweera, S., Tausz, M., Usui, Y. (2014). Increasing $\mathrm{CO}_{2}$ threatens human nutrition. Nature 510, 139-142. https://doi.org/10.1038/nature13179

Oikawa, S., Ainsworth, E.A. (2016). Changes in leaf area, nitrogen content and canopy photosynthesis in soybean exposed to an ozone concentration gradient. Environ Pollut. 215, 347-355. https://doi.org/10.1016/j.envpol.2016.05.005

Pfister, G.G., Walters, S., Lamarque, J.F., Fast, J., Barth, M.C., Wong, J., Done, J., Holland, G., Bruyère, C.L. (2014). Projections of future summertime ozone over the US. J. Geophys. Res. 119, 5559-5582. https://doi.org/10.1002/2013JD020932

Phothi, R., Umponstira, C., Sarin, C.S.W., Nabheerong, N. (2016). Combining effects of ozone and carbon dioxide application on photosynthesis of Thai jasmine rice (Oryza sativa L.) cultivar KhaoDawk Mali 105. Aust. J. Crop Sci. 10, 591-597. https://doi.org/10.21475/ajcs.2016.10.04. p7595x

Pingale, B.N., Singh, S.D., Yadav, A. (2017). Potential impacts of increasing atmospheric carbon dioxide on yield and plant growth of rice (Oryza sativa) and maize (Zea mays) crops. J. Agric Sci. 87, 1041-44. http://epubs.icar.org.in/ejournal/index.php/IJAgS/article/view/73235

Pleijel, H., Hogy, P. (2015). $\mathrm{CO}_{2}$ dose response functions for wheat grains, protein and mineral yield based on FACE and open top chamber experiments. Environ. Pollut. 198, 70-77. https://doi.org/10.1016/j.envpol.2014.12.030

Pleijel, H., Broberg, M.C., Uddling, J., Mills, G. (2018). Current surface ozone concentrations significantly decrease wheat growth yield and quality. Sci Total Environ. 613-614, 687-692. 
https://doi.org/10.1016/j.scitotenv.2017.09.111

Porter, J.R., Xie, L., Challinor, A.J., Cochrane, K., Howden, M., Iqbal, M.M., Lobell, D.B., Travasso, M.I. (2014). Chapter 7. Food Security and Food Production Systems. Climate Change 2014: Impacts, Adaptation and Vulnerability. Working Group II Contribution to the IPCC 5th Assessment Report. Geneva, Switzerland. https://orcid.org/0000-0002-8551-6617

Proietti, C, Anav, A., De Marco, A., Sicard, P., Vitale M. (2016). A multi-sites analysis on the ozone effects on Gross Primary Production of European forests. Sci Total Environ. 556, 1-8. https://doi.org/10.1016/j.scitotenv.2016.02.187

Reich, Peter. B., Hobbie, S.E., Lee, T.D., Pastore, M.A. (2018). Unespected reversal of $C_{3}$ verses $C_{4}$ grass response to elevated $\mathrm{CO}_{2}$ during a 20 year field experiment. Science 360, 317-320. https://doi.org/10.1126/science.aas 9313

Sadasivam, S., Manickam, A. (1992). In Biochemical Methods for Agricultural Sciences, Wiley Eastern Limited, New Delhi, pp. 12-13.

Sicard, P., Anav, A., De Marco, A., Paoletti, E. (2017). Projected global ground-level ozone impacts on vegetation under different emission and climate scenarios. Atmos. Chem. Phys. 17, 1217712196. https://doi.org/10.5194/acp-17-12177-2017

Singh, A.A., Agrawal, S.B., Shahi, J.P., Agrawal, M. (2014). Assessment of growth and yield losses in two Zea mays L. cultivars (quality protein maize and non-quality protein maize) under projected levels of ozone. Environ. Sci. Pollut. Res. 21, 2628-2641. https://doi.org/10.1007/s1 1356-013-2188-6

Singh, A.A., Agrawal, S.B. (2017). Tropospheric ozone pollution in India: Effects on crop yield and product quality. Environ. Sci. Pollut. Res. 24, 4367-4382. https://doi.org/10.1007/s11356-0168178-8

Singh, E., Rai, R., Pandey, B., Agrawal, M. (2018). Development of resistance in two wheat cultivars against constant fumigation of ozone. Proc. Natl. Acad. Sci., India, Sect. B 88, 11211134. https://doi.org/10.1007/s40011-017-0849-9

Tai, A.P.K., Val Martin, M., Heald, C.L. (2014). Threat to future global food security from climate change and ozone air pollution. Nat. Clim. Change 4, 817-821. https://doi.org/10.1038/nclim ate2317

Tomer, R., Bhatia, A., Kumar, V., Kumar, A., Singh, R., Singh, B., Singh, S.D. (2015). Impact of elevated ozone on growth, yield and nutritional quality of two wheat species in Northern India. Aerosol Air Qual. Res. 15, 329-340. https://doi.org/10.4209/aaqr.2013.12.0354

Torbert, H.A., Prior, S.A., Rogers, H.H., Runion, G.B. (2004). Elevated atmospheric $\mathrm{CO}_{2}$ effects on $\mathrm{N}$ fertilization in grain sorghum and soybean. Field Crops Res. 88, 57-67. https://doi.org/10.10 16/j.fcr.2003.11.011

Tsai, C.Y., Hansel, L.W., Nelson, O.E. (1972). Caloric method of screening maize seeds for lysine content. Cereal Chem. 49, 572-579.

van der Kooi, C.J., Reich, M., Löw, M., De Kok, L.J., Tausz, M. (2016). Growth and yield stimulation under elevated $\mathrm{CO}_{2}$ and drought: A meta-analysis on crops. Environ. Exp. Bot. 122, 150-157. https://doi.org/10.1016/j.envexpbot.2015.10.004

Wellburn, A.R. (1994). The spectral determination of chlorophylls a and b, as well as total carotenoids, using various solvents with spectrophotometers of different resolution. J. Plant Physiol. 144, 307-313. https://doi.org/10.1016/S0176-1617(11)81192-2

$\mathrm{Xu}$, Z., Jiang, Y., Jia, B., Zhou, G. (2016). Elevated $-\mathrm{CO}_{2}$ response of stomata and its dependence on environmental factors. Plant Cell Sci. 7, 657-563. https://doi.org/10.3389/fpls.2016.00657

Yendrek, C.R., Erice, G., Montes, C.M., Tomaz, T., Sorgini, C.A., Brown, P.J., Mclntyre, L.M., Leakey, A.D., Ainsworth, E.A. (2017). Elevated ozone reduces photosynthetic carbon gain by accelerating leaf senescence of inbred and hybrid maize in a genotype-specific manner. Plant Cell Environ. 40, 3088-3100. https://doi.org/10.1111/pce.13075

Zhang, R., Hu, H., Zhao, Z., Yang, D., Zhu, X., Guo, W., Zhu, J., Kobayashi, K. (2013). Effects of elevated ozone concentration on starch and starch synthesis enzymes of Yangmai 16 under fully open-air field conditions. J. Integr. Agric. 12, 2157-2163. https://doi.org/10.1016/S20953119(13)60345-7

Zhou, X., Zhou, J., Wang, Yunxia, Peng, B., Zhu, J., Yang, L., Wang, Y. (2015). Elevated tropospheric ozone increased grain protein and amino acid content of a hybrid rice without manipulation by planting density. J. Sci. Food Agric. 95, 72-78. https://doi.org/10.1002/jsfa.6684 
Zhu, C., Kobayshi, K., Loladze, I., Zhu, J.,Jiang, Q., Xu, X.,Liu, G., Seneweera, S.,Ebi, K.L., Drewnowski, A., Fukagawa, N.K., Zisla, L.H. (2018). Carbon dioxide $\left(\mathrm{CO}_{2}\right)$ levels this century will alter the protein, Micronutrients and vitamin content of rice grains with potential health consequences for the poorest rice-dependent countries. Sci. Adv. 4, 1-8. https://doi.org/10.1 126/sciadv.aaq1012

Zhu, X., Feng, Z., Sun, T., Liu, X., Tang, H., Zhu, J., Guo, W., Kobayashi, K. (2011). Effects of elevated ozone concentration on yield of four Chinese cultivars of winter wheat under fully open-air field conditions. Global Change Biol. 17, 2697-2706. https://doi.org/10.1111/j.13652486.2011.02400.x 